\title{
ISOLASI DAN PEMURNIAN WEDELOLAKTON DARI TUMBUHAN URANG ARING (Eclipta alba L. Hassk)
}

\author{
ISOALATION AND PURIFICATION OF WEDELOLACTONE FROM \\ (Eclipta alba L. Hassk) PLANT
}

\author{
Trisna Yuliana \\ Kopertis Wilayah IV Jabar - Banten, Bandung, Jawa Barat, Indonesia \\ Email : trisyuliana@yahoo.com
}

Diterima : 4 Nopember 2012, Direvisi : 7 Januari 2013, Disetujui : 23 Januari 2013

\begin{abstract}
ABSTRAK
Wedelolakton memiliki berbagai aktifitas biologis sehingga banyak digunakan untuk pengobatan berbagai penyakit. Dalam penelitian ini telah dikaji metode isolasi wedelolakton dari tumbuhan urang aring Eclipta alba L. Hassk untuk memperoleh wedelolakton murni. Proses isolasi dilakukan secara konvensional menggunakan cara maserasi, partisi, dan kromatografi kolom serta dikarakterisasi dengan menggunakan spektroskopi NMR, UV-Vis dan Massa. Hasil percobaan menunjukkan bahwa proses isolasi yang dilakukan menghasilkan wedelolakton dengan kemurnian 94\% yang diharapkan dapat digunakan sebagai standar.
\end{abstract}

Kata kunci : Wedelolakton, Eclipta alba L. Hassk, proses isolasi, pemurnian, kromatografi.

\section{ABSTRACT}

Wedelolactone has a wide range of biological activities and used for the treatment of various ailment. In the present study an experiment of isolation method of wedelolactone from Eclipta alba L. Hassk plant has been developed by conventional process using maceration method, partitions, and column chromatography and the result was characterized by NMR, UV-Vis and mass spectroscopy. The experimental results showed that the process of isolation isproduce wedelolactone with $94 \%$ purity which are expected to be used as a standard.

Keywords: Wedelolactone, Eclipta alba L. Hassk, isolation process, purification, chromatography.

\section{PENDAHULUAN}

Wedelolakton, 7-Metoksi-5,11,12-trihidroksi kumestan, $\mathrm{C}_{16} \mathrm{H}_{10} \mathrm{O}_{7}$, $\mathrm{BM} 314,25$. dan strukutur kimia ditampilkan pada Gambar 1 merupakan senyawa organik turunan kumestan yang terdapat dalam tumbuhan urang aring (Eclipta alba (L.) Hassk). Secara tradisional daun urang-aring banyak digunakan untuk mengobati sesak nafas, sakit kepala, sakit gigi, bronkhitis, gangguan haid, dan sebagai penyubur rambut ${ }^{(1)}$. Wedelolakton merupakan marker bioaktif dari urang-aring yang paling banyak dicari oleh industri obat-obatan dan herbal karena memiliki berbagai fungsi. Dari hasil skrining farmakologi dari tumbuhan ataupun hasil sintesa diungkapkan bahwa wedelolakton mempunyai aktifitas sebagai antihepatotoksik ${ }^{(2)}$, immunomodulator ${ }^{(3)}$, antioksidan ${ }^{(4)}$, anti radang ${ }^{(5)}$, penawar racun bisa ular ${ }^{(6-8)}$, penghambat virus hepatitis $\mathrm{C}^{(9)}$, analgesik ${ }^{(10)}$, antiosteoporetik ${ }^{(11)}$, menekan aktifitas dan pertumbuhan androgen dalam sel kanker prostat secara sinergis ${ }^{(12)}$, efek farmakologis pada sistem saraf $^{(13)}$, anti HIV ${ }^{(14)}$, dan anti bakteri ${ }^{(15)}$.

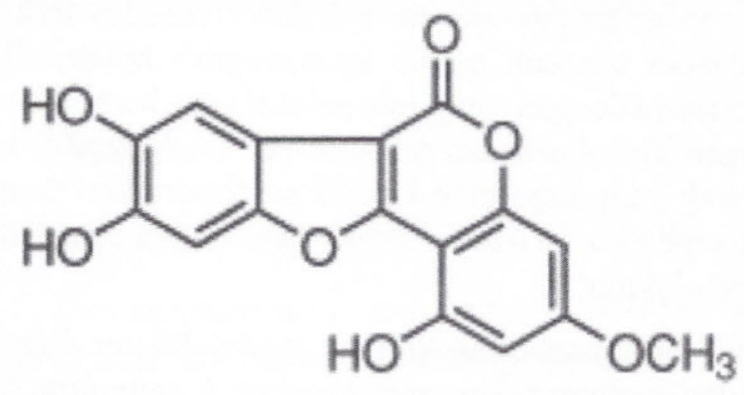

\section{Gambar 1. Struktur kimia Wedelolakton, $\mathrm{C}_{16} \mathrm{H}_{10} \mathrm{O}_{7}$, BM 314,25}

Beberapa teknik isolasi wedelolakton telah dilakukan dari tumbuhan urang aring (Eclipta alba (L.) Hassk). Tewtrakul dkk. memperoleh wedelolakton dari tumbuhan utuh/lengkap ${ }^{(14)}$. Isolasi dilakukan dengan cara ekstraksi menggunakan diklorometan dan metanol secara berturutan pada suhu ruang. Terhadap ekstrak kasar metanol dilakukan fraksinasi menggunakan kolom kromatografi dengan heksan dan polaritas pelarut dinaikkan dengan diklorometan dan metanol secara berturutan untuk mendapatkan 4 buah fraksi (M1 - M4). Dari fraksi M4 didapatkan komponen wedelolakton melalui teknik kromatografi lapisan tipis (KLT) preparatif dengan menggunakan campuran metanol dan diklorometan $(5: 95)$ sebagai eluen. 
Pada tahun 2009, Dalal dkk. melakukan isolasi wedelolakton dari tumbuhan yang telah dikeringkan melalui teknik soxhletasi dengan pelarut metanol selama 36 jam. Setelah metanol diuapkan kemudian ditambahkan air suling dan dipanaskan kembali selama 30 menit pada suhu di bawah $80^{\circ} \mathrm{C}$. Bagian air kemudian diekstraksi dengan pelarut etil asetat. Terhadap ekstrak etil asetat yang didapat kemudian dilakukan proses kromatografi kolom dengan silika gel dan dielusi dengan pelarut organik dengan polaritas yang meningkat dari non polar - polar - polaritas tinggi. Kombinasi pelarut yang digunakan adalah kloroform dan metanol $(70: 30)$ dielusi secara serempak dalam 37 hingga 48 fraksi. Fraksi yang terkumpul kemudian dilakukan proses pemisahan menggunakan KLT dengan sistem eluen toluen : aseton : asam format $(11: 6: 1)$ menghasilkan dua noda ${ }^{(15)}$.

Sun, dkk. (2010) melakukan isolasi dari tumbuhan urang aring dalam jumlah yang cukup besar menggunakan etanol (80\%) dengan teknik refluk sebanyak tiga kali. Setelah etanol diuapkan, ekstrak kemudian disuspensi dalam air suling dan dilakukan proses ekstraksi dengan etil asetat. Fraksi etil asetat yang diperoleh kemudian diuapkan dan dilakukan proses kromatografi kolom menggunakan silika gel dengan campuran pelarut diklorometan, metanol dan air (14: 9: 4) hingga didapat 9 fraksi. Terhadap fraksi 4 dilakukan kembali proses kromatografi kolom silika akan tetapi dengan campuran pelarut yang berbeda yaitu dengan kloroform dan metanol (20: 1 hingga $5: 1)$. Ekstrak yang diperoleh kemudian dimurnikan dengan alat sephadex LH-20 kromatografi hingga didapatkan wedelolakton ${ }^{(16)}$.

Pada penelitian kali ini wedelolakton diisolasi dengan menggunakan aseton sebagai campuran fasa gerak dan menggunakan teknik pemurnian wedelolakton yang berbeda yaitu hanya dengan kromatografi kolom konvensional. Diharapkan dengan proses ini diperoleh cara alternatif yang relatif lebih mudah dan murah untuk diisolasi sehingga dapat diperoleh komponen wedelolakton dengan kemurnian yang cukup tinggi yang dapat digunakan untuk berbagai keperluan seperti sebagai standar dalam proses validasi metode, penentuan nilai kandungan wedelolakton dalam sampel ataupun untuk penelusuran uji aktifitas lainnya.

\section{BAHAN DAN METODA}

\section{Bahan}

Bahan yang digunakan dalam penelitian ini adalah bagian daun Eclipta alba (L.) Hassk beserta tangkainya yang telah dikeringkan. Daun ini diambil dari kebun Balitro pada bulan Agustus 2010. Standar Wedelolakton (E. Merck) yang digunakan sebagai pemandu (acuan). Berbagai jenis pelarut organik teknis yang didestilasi ulang seperti $n$-heksan, etil asetat, metanol, dan aseton. Silika gel $\mathrm{GF}_{254}$ untuk kromatografi lapis tipis dan silika gel (230-400 mesh) untuk kromatografi kolom terbuka, pereaksi penampak noda besi klorida dalam etanol, air suling, asam asetat, toluen, aseton dan asam format.

\section{Peralatan}

Peralatan yang digunakan merupakan peralatan umum yang biasa digunakan di Laboratorium Kimia seperti peralatan gelas, rotary evaporator, spektrofotometer UV-Vis, seperangkat peralatan NMR 9,4 Tesla $\left({ }^{1} \mathrm{H}\right.$ pada $400 \mathrm{MHz}$ dan ${ }^{13} \mathrm{C}$ pada $100 \mathrm{MHz}$ ) di Graduate School of Life \& Environment Sciences, Osaka Prefecture University, Jepang. dan LC-MS di Pusat Penelitian Kimia - LIPI Serpong, untuk karakterisasi isolat wedelolakton.

\section{Metoda Penelitian}

Daun dan tangkai daun urang aring (Eclipta alba L. Hassk) setelah dikeringkan pada suhu kamar kemudian diremukkan dan dimaserasi dengan metanol tiga kali berturutan masing-masing selama 24 jam. Gabungan ekstrak metanol hasil tiga kali ulangan maserasi diuapkan pada tekanan rendah hingga diperoleh ekstrak metanol pekat. Ekstrak metanol pekat yang diperoleh kemudian dilarutkan dengan air dan diekstraksi berulang dengan $n$-heksan sampai diperoleh fraksi $n$-heksan yang jernih. Fraksi $n$-heksan yang diperoleh kemudian dikumpulkan. Selanjutnya fraksi air diekstraksi dengan etil asetat. Proses ekstraksi dengan etil asetat pun dilakukan berulang hingga didapat fraksi etil asetat relatif jernih. Hanya fraksi etil asetat yang selanjutnya akan diteliti. Setelah pelarut diuapkan didapat fraksi etil asetat pekat (FEAP) kemudian dilarutkan dalam aseton dan ditambahkan silika gel sebanyak kira kira dua kali massa ekstrak etil asetat. Campuran diaduk sampai merata, kemudian dikeringkan untuk menguapkan aseton. Campuran FEAP-silika gel kering tersebut diletakkan diatas fasa diam dalam kolom kromatografi terbuka. Kolom dielusi secara gradien menggunakan campuran n-heksan:etil asetat:metanol (10\%) menjadi 21 fraksi (A1 - A21). Setelah dianalisis menggunakan kromatografi lapis tipis dengan panduan standar wedelolakton dan larutan penampak noda, eluat yang teridentifikasi positif wedelolakton digabungkan menjadi satu fraksi. Ekstrak kemudian dimurnikan dengan kromatografi kolom dan sistem elusi yang sama akan tetapi menggunakan pelarut berbeda yaitu $n$-heksan:aseton:metanol. Fraksi (B) yang teridentifikasi positif kemudian digabung, 
diuapkan dan ditambahkan aseton. Padatan dan cairan yang didapat kemudian diuji dengan KLT menggunakan fasa gerak toluen:aseton:asam format (11:6:1) dan dikarakterisasi dengan spektroskopi UV-Vis untuk pengukuran panjang gelombang maksimum, resonansi magnet inti dan massa. Hasil karakterisasi kemudian dibandingkan terhadap referensi. Ringkasan prosedur isolasi ini ditunjukkan pada Gambar 2.

\section{HASIL DAN PEMBAHASAN}

Dari 1 (satu) $\mathrm{kg}$ daun kering yang dimaserasi 24 jam dengan tiga kali ulangan menggunakan metanol kurang lebih $10 \mathrm{~L}$ diperoleh $136 \mathrm{~g}$ ekstrak metanol pekat. Selanjutnya, ekstrak metanol pekat ini ditambahkan air $500 \mathrm{~mL}$ dan diaduk sehingga homogen. Berikutnya campuran ini diekstraksi berturut-turut dengan pelarut n-heksana dan etil asetat. Fraksi etil asetat yang diduga mengandung komponen target yang cenderung semi polar, diuapkan pelarutnya dan diperoleh FEAP sebanyak 2,78 g. Pemisahan dengan kromatografi kolom terbuka menggunakan fasa mobil campuran $n$-heksana - etil asetat - metanol diperoleh 21 fraksi.

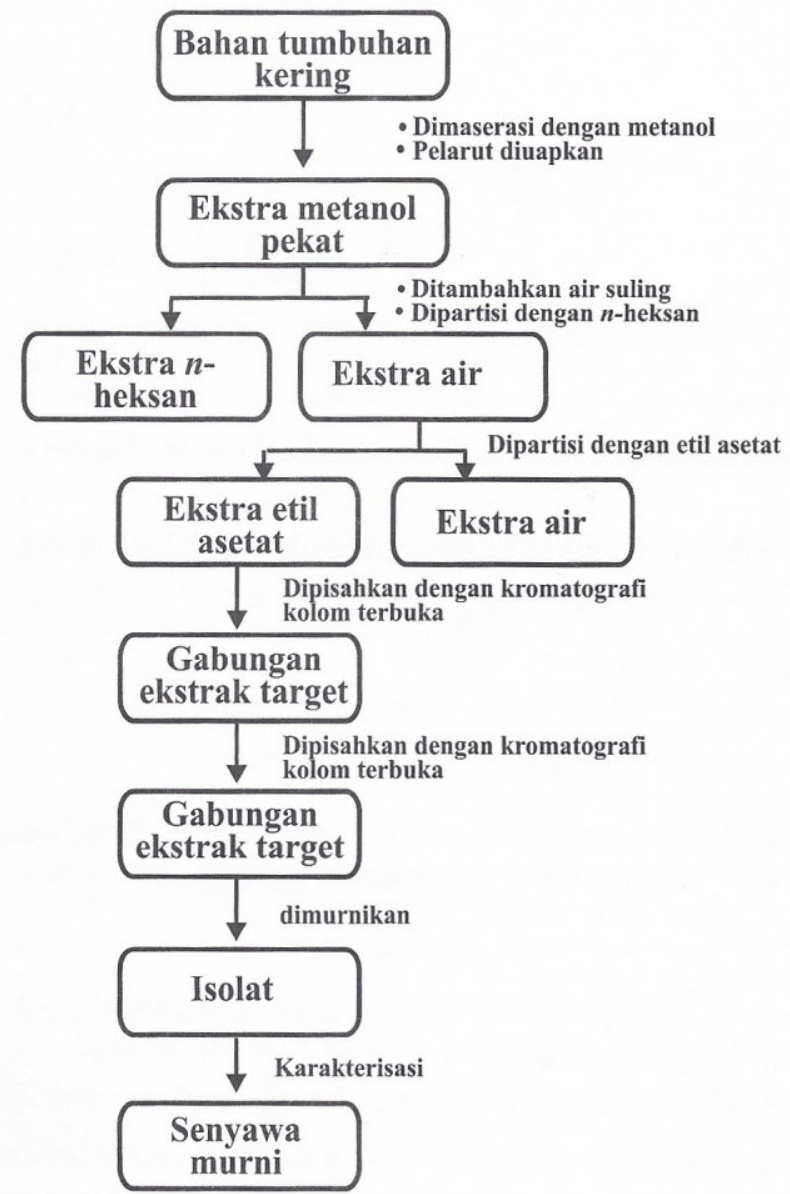

Gambar 2. Bagan prosedur isolasi wedelolakton dari daun urang aring
Hanya fraksi A7 hingga A11 teridentifikasi positif wedelolakton melalui perbandingan dengan noda standar wedelolakton pada KLT. Sejumlah 0,86 g ekstrak positif kemudian dimurnikan dengan menggunakan kolom kromatografi terbuka menggunakan fasa gerak campuran $n$-heksan, aseton dan metanol dengan kepolaran yang ditingkatkan. Aseton dipilih untuk menggantikan etil asetat karena pada percobaan pertama dengan menggunakan etil asetat tidak diperoleh isolat yang diinginkan. Kemungkinan hal ini disebabkan polaritas komponen wedelolakton lebih tinggi dibanding dengan polaritas etil asetat. Berdasarkan indeks polaritas pelarut dari Solvent Miscibility \& Viscosity Chart, etil asetat memiliki indeks polaritas sebesar 4,4 sementara indeks polaritas aseton 5,1. (Anonymous). Semakin tinggi nilai indeks polaritas maka semakin polar suatu pelarut. Pemilihan aseton inipun dikuatkan oleh $\mathrm{Li}$, dkk. yang menggunakan pelarut aseton di dalam proses karakterisasi wedelolakton hasil sintesis dengan

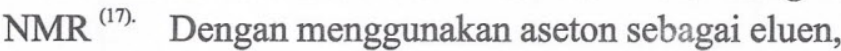
diperoleh 8 fraksi (B5 sampai B12) yang teridentifikasi positif wedelolakton. Gabungan fraksi tersebut selanjutnya diuapkan kemudian ditimbang dan diperoleh hasil sebanyak $612 \mathrm{mg}$ ekstrak. Endapan putih sebanyak $55 \mathrm{mg}$ diperoleh setelah ekstrak hasil gabungan fraksi tersebut ditambahkan aseton sedikit demi sedikit.

\section{Karakterisasi}

\section{Analisis menggunakan spektroskopi ${ }^{13} \mathrm{C}-\mathrm{NMR}$}

Berdasarkan data spektrum 13C-NMR pada Gambar 3. Daerah geseran kimia (ppm) sebagai absis dan respon sebagai ordinat. Terdapat 16 (enam belas) atom karbon yang terbagi atas dua sinyal karbon yaitu jenis karbon $s p^{2}$ dan $s p^{3}$. Umumnya karbon-karbon $s p^{2}$ dapat teramati pada daerah geseran kimia $(\delta \mathrm{C})$ lebih dari $100 \mathrm{ppm}$ dan karbon-karbon $s p^{3}$ dapat teramati pada $\delta_{\mathrm{C}}$ hingga sekitar $100 \mathrm{ppm}$.

Pada daerah $\delta_{\mathrm{c}}$ diatas $100 \mathrm{ppm}$ terdapat delapan atom karbon $s p^{2}$ teroksigenasi yaitu pada rentang $\delta_{\mathrm{c}}$ antara 145,2 hingga 163,1 . Tujuh atom karbon $s p^{2}$ teramati pada daerah $94,0-114,5 \mathrm{ppm}$. Dan satu gugus karbonil $(\mathrm{C}=\mathrm{O})$ pada $\delta_{\mathrm{c}} 155,8 \mathrm{ppm}$. Karbon $s p^{3}$ teroksigenasi teramati pada $\delta_{\mathrm{C}} 56,6 \mathrm{ppm}$ menunjukkan daerah karbon metoksi.

Apabila dibandingkan terhadap hasil sintesis yang dilaporkan oleh $\mathrm{Li}, \mathrm{dkk} .{ }^{(17)}$ seperti yang tertera pada Gambar 4, hasil percobaan menunjukkan profil spektrum ${ }^{13} \mathrm{CNMR}$ yang sama. 


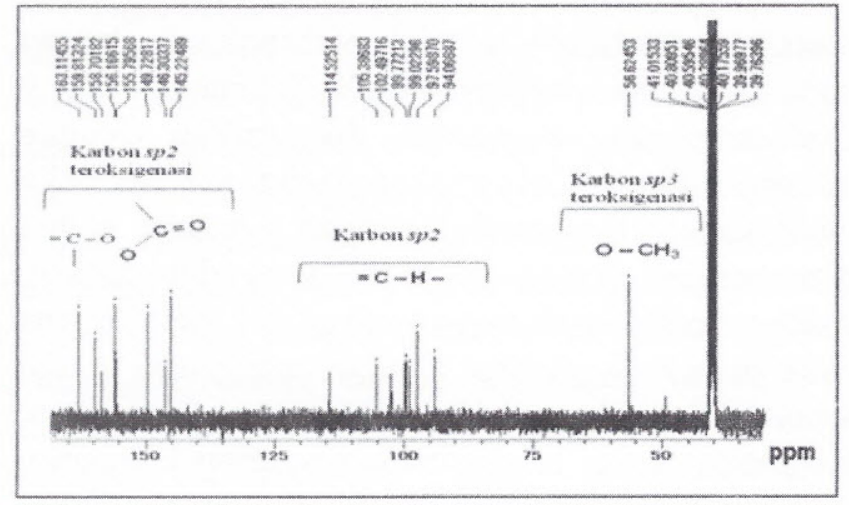

Gambar 3. Spektrum ${ }^{13} \mathrm{CNMR}$ senyawa wedelolakton hasil isolasi $\left(\mathrm{DMSO}\left(\mathrm{d}_{6}\right), 100 \mathrm{MHz}\right)$

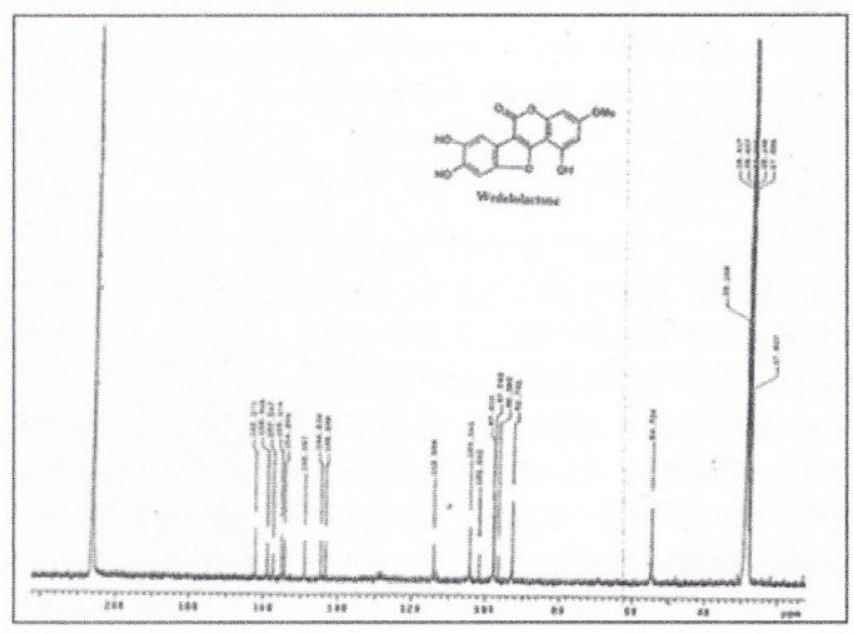

Gambar 4. Spektrum ${ }^{13}$ CNMR senyawa wedelolakton hasil sintesis ${ }^{(17)}$

\section{Analisis menggunakan spektroskopi ${ }^{1} \mathrm{H}-\mathrm{NMR}$}

Berdasarkan hasil analisis spektrum ${ }^{1} \mathrm{H}-\mathrm{NMR}$ pada Gambar 5 dimana daerah geseran kimia (ppm) sebagai absis dan respon sebagai ordinat. Pada gambar tersebut, terdapat 7 (tujuh) buah proton pada komponen isolat yang terdiri dari empat kelompok proton $s p 2$ pada daerah pergeseran kimia $(\delta) 6,4$ - 7,5 dan satu kelompok proton $s p^{3}$. Proton - proton ini terdiri atas dua gugus metin $(\mathrm{CH})$ dengan sinyal tunggal (singlet) yaitu pada daerah $\delta 7,4$ dan 7,2 ; dua gugus metin $(\mathrm{CH})$ dengan sinyal ganda $($ doublet $)$ pada daerah $\left[\delta_{\mathrm{H}}(\mathrm{ppm})=6,6(1 \mathrm{H}\right.$, d)] dan $\left[\delta_{\mathrm{H}}(\mathrm{ppm})=6,5(1 \mathrm{H}, d)\right]$; serta satu gugus metil $\left(\mathrm{CH}_{3}\right)$ yang mengikat atom oksigen yang ditunjukkan oleh sinyal pada $\left[\delta_{\mathrm{H}}(\mathrm{ppm})=3,9(3 \mathrm{H}, s)\right]$. Apabila dibandingkan terhadap hasil sintesis yang dilaporkan oleh Li, dkk. ${ }^{(17)}$ yaitu yang tertera pada Gambar 6 hasil percobaan menunjukkan profil spektrum ${ }^{1} \mathrm{HNMR}$ yang sama.

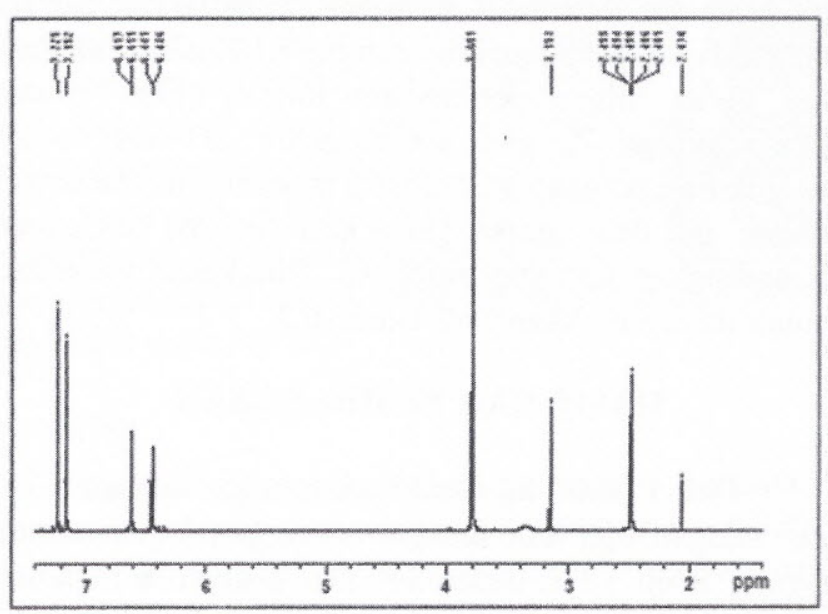

Gambar 5. Spektrum ${ }^{1} \mathrm{HNMR}$ wedelolakton hasil isolasi $\left(\operatorname{DMSO}\left(\mathrm{d}_{6}\right), 400 \mathrm{MHz}\right)$

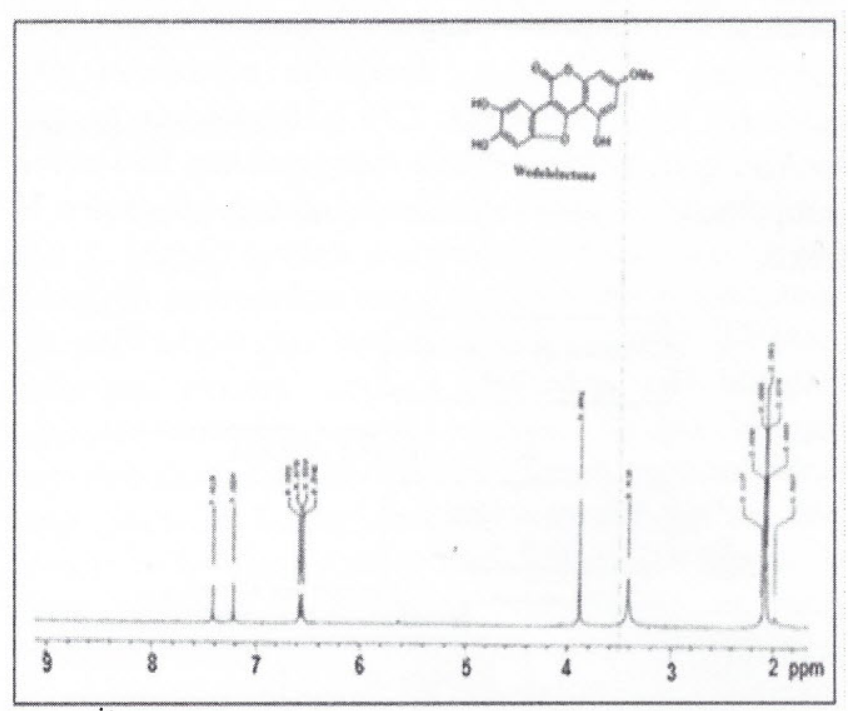

Gambar 6. Spektrum ${ }^{1} \mathrm{HNMR}$ wedelolakton hasil sintesis ${ }^{(17)}$

Tabel 1. Ringkasan hasil pengukuran NMR isolat

\begin{tabular}{|c|c|c|c|c|c|c|}
\hline $\begin{array}{l}\text { Posisi } \\
\text { Karbon }\end{array}$ & $\delta_{\mathrm{c}}$ & $\delta_{C}^{(17)}$ & $\delta_{c}^{(18)}$ & $\delta_{\mathrm{H}}$ & $\delta_{H}^{(117)}$ & $\delta_{H}{ }^{(18)}$ \\
\hline 1 & 155,8 & 154,3 & 155,2 & - & - & \\
\hline 2 & 102,5 & 101,6 & 102,2 & - & - & \\
\hline 3 & 163,1 & 162,3 & 162,7 & - & - & \\
\hline 4 & 105,4 & 104,1 & 104,8 & $\cdot$ & - & \\
\hline 5 & 158,7 & 157,5 & 157,8 & $\cdot$ & - & $10,56(\mathrm{br} \mathrm{s}, \mathrm{IH})$ \\
\hline 6 & 94,1 & 92,7 & 93 & $6,44(\mathrm{~d}, J=2,4 \mathrm{~Hz}, 1 \mathrm{H})$ & $6,55(\mathrm{~d}, J=2,4 \mathrm{~Hz}, 1 \mathrm{H})$ & $6,51(\mathrm{~s}, 1 \mathrm{H})$ \\
\hline 7 & 159,8 & 158,9 & 159,4 & - & - & \\
\hline 8 & 99,0 & 97,6 & 98,2 & $6,61(\mathrm{~d}, J=2 \mathrm{~Hz}, 1 \mathrm{H})$ & $6,58(\mathrm{~d}, J=2,1 \mathrm{~Hz}, 1 \mathrm{H})$ & $6,53(\mathrm{~s}, 1 \mathrm{H})$ \\
\hline 9 & 156,2 & 155,2 & 155,8 & & & \\
\hline 10 & 99,8 & 97,8 & 98,5 & $7,22(\mathrm{~s}, 1 \mathrm{H})$ & $7,41(\mathrm{~s}, 1 \mathrm{H})$ & $7,37(\mathrm{~s}, 1 \mathrm{H})$ \\
\hline 11 & 145,2 & 143,4 & 144,3 & - & - & $8,81$ (br s, $1 \mathrm{H})$ \\
\hline 12 & 146,3 & 144,6 & 145,5 & $\cdot$ & - & $8,85(\mathrm{br} \mathrm{s}, 1 \mathrm{H})$ \\
\hline 13 & 97,6 & 96,4 & 97 & $7,15(\mathrm{~s}, 1 \mathrm{H})$ & $7,22(\mathrm{~s}, 1 \mathrm{H})$ & $7,17(\mathrm{~s}, 1 \mathrm{H})$ \\
\hline 14 & 149,7 & 149 & 149,5 & - & - & \\
\hline 15 & 114,5 & 114 & 114,5 & 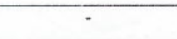 & - & \\
\hline $\mathrm{CH}_{3}-\mathrm{O}$ & 56,6 & 54,8 & 55,3 & $3,80(\mathrm{~s}, 3 \mathrm{H})$ & $3,89(\mathrm{~s}, 3 \mathrm{H})$ & $3,90(\mathrm{~s}, 3 \mathrm{H})$ \\
\hline
\end{tabular}


Tabel 1. merupakan hasil rekapitulasi pengukuran NMR hasil percobaan dan hasil referensi. Dari tabel tersebut terlihat spektrum proton dan karbon isolat berada pada daerah geseran kimia ( $\delta$ ) yang relatif sama dengan yang dilaporkan oleh $\mathrm{Li}$, dkk ${ }^{(17)}$. Ini menunjukkan bahwa berdasarkan pengukuran ${ }^{1} \mathrm{HNMR}$ dan ${ }^{13} \mathrm{CNMR}$, isolat hasil percobaan merupakan senyawa wedelolakton. Menurut Chang dkk., pada daerah sekitar 8 ppm menunjukkan daerah geseran kimia proton dari gugus $\mathrm{OH}$ yang tidak tajam (broad), tapi tidak dijelaskan mengenai lebar dan bentuk spektrumnya ${ }^{(18)}$. Menurut Creswell, dkk. ${ }^{(19)}$ adanya atom yang lebih elektronegatif dapat menyebabkan perlindungan berkurang (deshielding) sehingga proton akan hadir pada daerah geseran kimia () yang besar seperti yang tergambar pada spektrum isolat wedelolakton(Gambar 7).

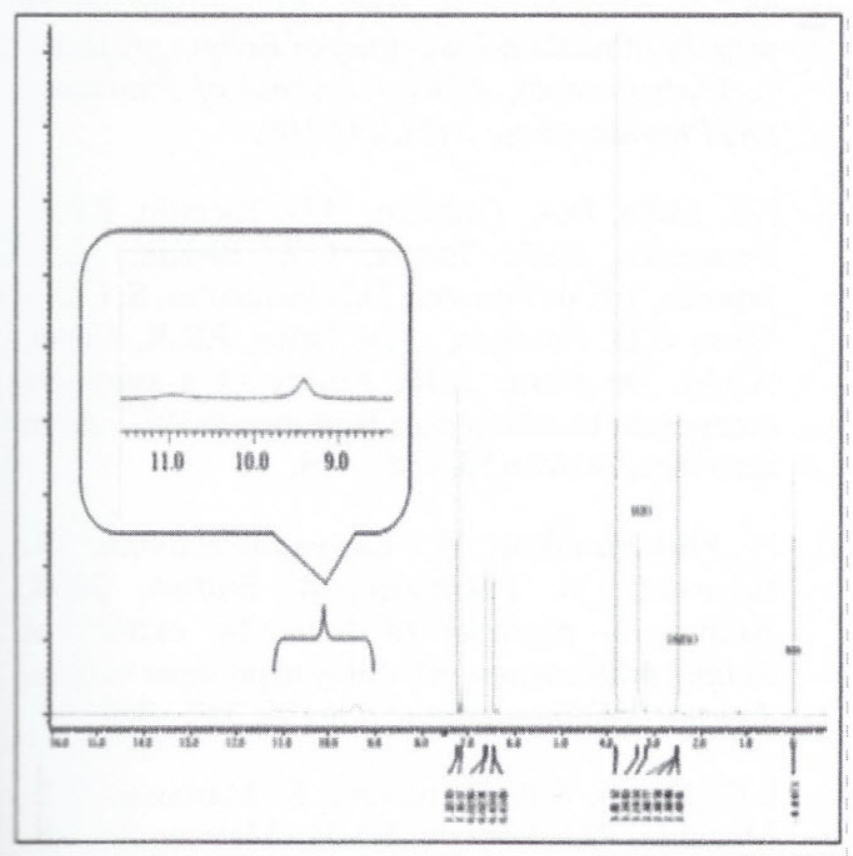

Gambar 7. Pengukuran ${ }^{1 \mathrm{H}} \mathrm{NMR}$ wedelolakton isolat hasil pengulangan (DMSO $\left(d_{6}\right), 500 \mathrm{MHz}$ )

\section{Pemindaian panjang gelombang maksimum}

Hasil pemindaian panjang gelombang maksimum menggunakan spektroskopi UV-Vis menunjukkan panjang gelombang maksimum senyawa wedelolakton hasil isolasi adalah $350 \mathrm{~nm}$ seperti tampak pada Gambar 8.

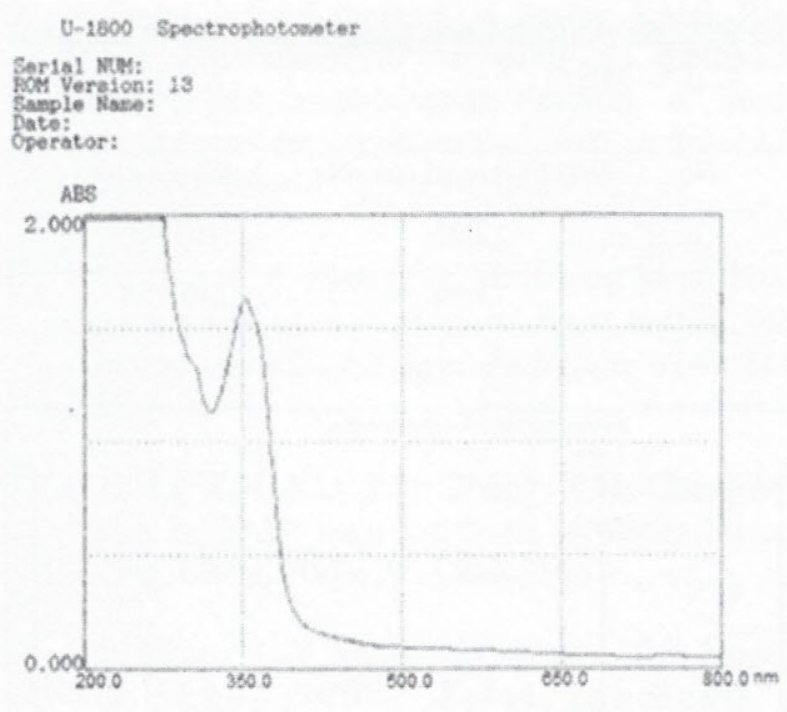

Gambar 8. Hasil pemindaian panjang gelombang maksimum wedelolakton hasil isolasi

\section{Analisis Kromatografi Cair - Spektroskopi Massa (LC-MS)}

Salah satu cara untuk mengkarakterisasi suatu isolat adalah melalui pengukuran massa molekul relatif (Mr). Pengukuran inipun dapat digunakan untuk melihat kemurnian suatu isolat. Pengukuran massa isolat wedelolakton dilakukan dengan menggunakan LC-MS. Pada Gambar 9 menunjukkan adanya dua puncak yang terdeteksi pada waktu retensi 2,2 dan 3,9 menit dengan luas puncak masing-masing 167,43 dan 2469,58 seperti yang tertera pada Tabel 2 . Berdasarkan luas puncak yang diperoleh pada Tabel 2, maka kemurnian wedelolakton dalam isolat dapat dihitung sebesar $94 \%$. Pada pengukuran massa yang dilakukan untuk waktu retensi 3,9 didapat massa yang terukur sebesar $\left.315,01([\mathrm{M}+\mathrm{H}]]^{\dagger}\right)$, atau $[\mathrm{M}]=314,0$ yang sesuai dengan Mr wedelolakton (Gambar 10).

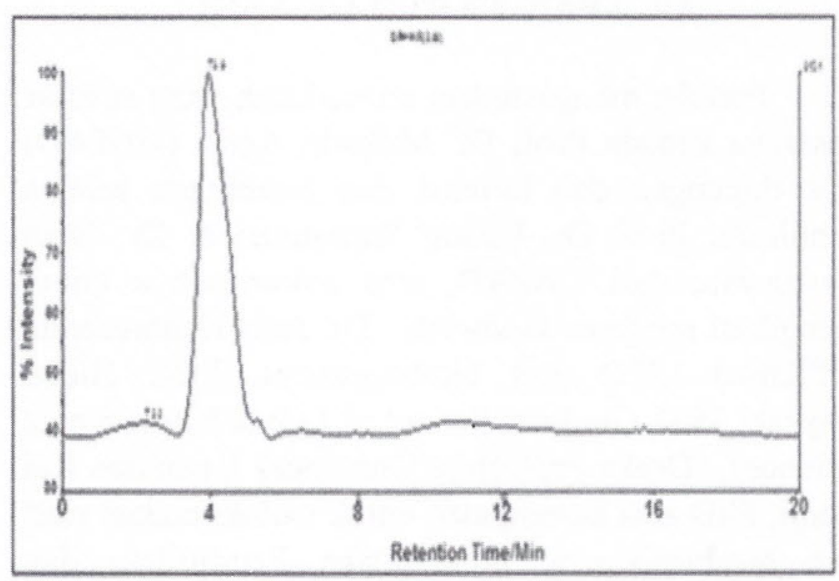

Gambar 9. Profil kromatogram dari isolat wedelolakton 
Tabel 2. Luas puncak hasil pengukuran isolat dengan LC-MS

\begin{tabular}{ccc}
\hline No & Waktu retensi (menit) & Luas puncak \\
\hline 1 & 2,25 & 167,43 \\
\hline 2 & 3,94 & 2469,58 \\
\hline
\end{tabular}

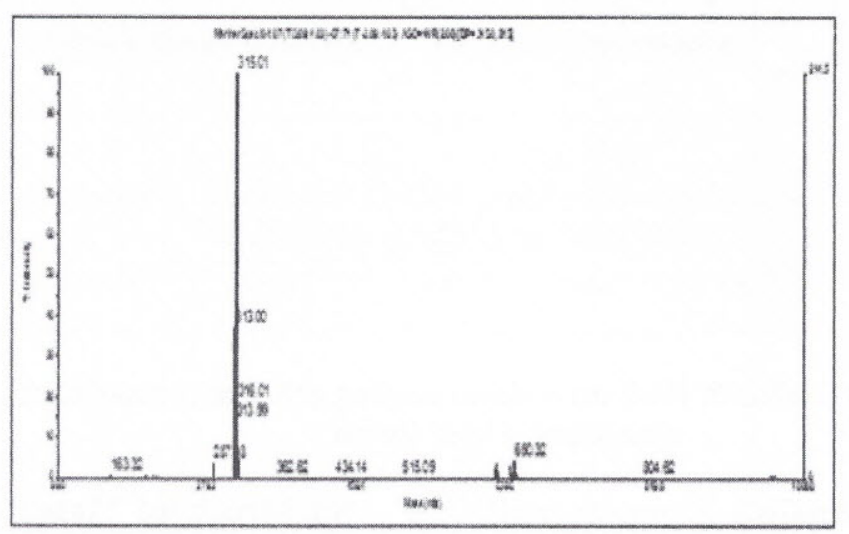

Gambar 10. Profil spektrum massa isolat wedelolakton pada waktu retensi $\left(t_{R}\right) 3,9$ menit

\section{KESIMPULAN}

Wedelolakton yang diperoleh dari proses isolasi menggunakan campuran pelarut aseton dengan teknik kromatografi kolom konvensional telah dikarakterisasi dan mempunyai kemurnian $94 \%$. Jumlah wedelolakton yang diperoleh sebanyak $55 \mathrm{mg}$ dari $1 \mathrm{~kg}$ daun kering. Wedelolakton isolat ini dapat digunakan sebagai standar dalam proses optimasi dan validasi metode juga dapat digunakan untuk kepentingan uji aktifitas.

\section{UCAPAN TERIMA KASIH}

Penulis mengucapkan terimakasih yang sebesar besarnya kepada Prof. Dr. Muljadji Agma (UNPAD) atas dukungan dan koreksi dan bimbingan selama penulisan. Prof. Dr. Unang Supratman \& Dr. Iwan Hastiawan, dari UNPAD, atas dukungannya untuk mengikuti program sandwich. Dr. Julia Kantasubrata (PPKimia LIPI) atas bimbingannya. Prof. Hideo Hayashi, $\mathrm{PhD}$, Graduate School of Life \& Environment Sciences, Osaka Prefecture University Japan dan Kai Kenji, $\mathrm{PhD}$ atas kesempatan untuk melaksanakan riset dan bimbingannya. Kementrian Pendidikan dan Kebudayaan Republik Indonesia atas dukungan dana untuk melaksanakan riset dalam program sandwich

\section{DAFTAR PUSTAKA}

1. K.P. Unnikhrishnan, Anu Fhatima, K.M. Hashim, I. Balachandran, 2007, Antioxidant Studies and Determination of Wedelolakton in Eclipta Albae, Journal of Plant Sciences 2(4):459-464

2. S.C. Franca, B.W. Bertoni, A.M.S. Pereira, 1995, Antihepatotoxic agent in micropropagated planlets of Eclipta alba. Plant Cell, Tissue and Organ Culture, 40:297-299.

3. M.G. Jayathirta, and S.H. Mishra, 2004, Preliminary immunomodulatory activities of methanol extracts of Eclipta alba and Centella asiatica. Phytomedicine, 11,(4), 361-365.

4. A.S. Majumdar, 2008, Preliminary studies on the antioxidant activity of Tribulus terrestris and Eclipta alba, Pharmacognosy Magazine, 4, (13), 102-107

5. G. Arunachalam, N. Subramanian, G.P. Pazhani, and V. Ravichandran, 2009, Anti-inflammatory activity of methanolic extract of Eclipta prostrata L. (Astearaceae), African Journal of Pharmacy and Pharmacology 3(3), 097-100.

6. P.A. Melo, D.A. Pinheiro, H.D. Ricardo, F.F.A. Fernandes, M.A. Tomaz, C.Z. El-Kik, M.A. Strauch, T.F. da Fonseca, D.N. Sifuentes, S. CalilElias, C.D. Buarque, F.V. Brito, P.R.R. Costa, A.J.M. Da Silva, 2010, Ability of a synthetic coumestan to antagonize Bothrops snake venom activities, Toxicon 55, 488-496.

7. P. Phitayanukul, S. Laovachirasuwan, R. Bavovada, N. Pakmanee, R. Suttisri, 2004, Antivenom potential of butanolic extract of Eclipta prostata against Malayan pit viper venom, Journal of Ethnopharmacology 90, 347-352.

8. L.C. Diogo, S.R. Fernandes, S. Marcussi, D.L. Menaldo, P.G. Roberto, P.V.F. Matrangulo, P.S. Pereira, S.C. Franca, S. Giuliatti, A.M. Soares, and M.V. Lourenco, 2009, Inhibition snake venoms and phospholipases $\mathrm{A} 2$ by extract from native and genetically modified Eclipta alba: isolation of actove compound, Basic \& Clinical Pharmacology \& Toxicology, 104, 293-299.

9. N.K. Basu, A.B. Waffol T.T. Talele, A. Basu, P.R.R. Costa, A.J.M. da Silva, S.G. Sarafianos, and F. Noel, 2008, Identification and characterization of coumestans as novel HCV NS5B polymerase inhibitors, Nucleic Acids Research, 36,(5), 1482-1496 
10. M. Sawant, J.C. Issac and S. Narayanan, 2004 Analgesic Studies on Total alkaloids and alcohol extracs of Eclipta alba (Linn.) Hask. Phytother.Res. 18(2): 111-113.

11. S. Annie, R.G. Prabhu, S. Malini, 2006, Activity of Wedelia calendulacea Less. in post-menopausal osteoporosis, Phytomedicine 13,43-48.

12. F.M. Lin, L.R. Chen, E.H. Lin, F.C. Ke, H.Y.Chen, M. Tsai, and P.W. Hsiao, 2007, Compound from Wedelia chinesnsis synergistically suppress androgen activity and growth in prostate cancer cells, Carcinogenesis 28(12), 2521-2529.

13. T. Prakash, N.R. Rao A.H.M.V. Swamy, 2008, Neuropharmacological studies on Wedelia calendulacea Less stem extract, Phytomedicine 15,959-970.

14. S. Tewtrakul, S. Subhadhirasakul, S. Cheenpracha, anD C. Karalai, 2007, HIV-1 Protease and HIV-1 integrase inhibitory substances from Eclipta prostrate, Phytotherapy research, 21, 1092-1095.
15. S. Dalal, S.K. Kataria, K.V. Sastry, S.V.S. Rana, 2010, Phytochemical screening of methanolic extract and antibacterial activity of active principles of hepatoprotective herb, eclipta alba, Ethnobotanical Leaflets 14:248-58

16. Z.H. Sun, C.F. Zhang, \& M. Zhang M., 2010, A new benzoic acid derivatives from Eclipta alba, Chinese journal of natural medicines, 8 (4): 244 246.

17. C.C. Li, Z.X. Xie, Y.D. Zhang, Z.H. Chen, \& Z. Yang, Z., 2003, Total Synthesis of Wedelolactone, J. Org. Chem. 2003, 68, 8500-8504

18. C.F. Chang, L.Y. Yang, S.W. Chang, Y.T. Fang, \& Y.J. Lee, 2008, Total synthesis of demethylwedelolactone and wedelolactone by $\mathrm{Cu}$-mediated $/ \mathrm{Pd}(0)$-catalysis and oxidativecyclization, Tetrahedron 64, 3661-3666

19. C.J. Creswell, O.A. Runquist, \& M.M. Campbell, 1982, Analisis spektrum senyawa organik, Terjemahan Kosasih Padmawinata dan Iwang Soediro, ITB, hal 104-110. 